\title{
Parentelas, grupos dirigentes e alianças políticas
}

\author{
Fernanda Rios Petrarca' \\ Wilson José Ferreira de Oliveira ${ }^{2}$
}

\section{Resumo}

Este artigo demonstra que o conceito de parentela constitui uma importante contribuição heurística, na medida em que nos permite apreender o papel central que desempenharam os laços sociais e o sistema de alianças nas dinâmicas de composição e de recomposição dos grupos dirigentes. Tal abordagem visa fornecer elementos para um deslocamento dos debates sobre a politização como consequência da separação e interferência entre ordens de atividades distintas e autônomas. Isto requer uma maior atenção à descrição das múltiplas formas de dominação e organização políticas e, principalmente, a ruptura com as clivagens e antagonismos entre as sociedades fundadas em pressupostos e ideologias eurocêntricas.

Palavras-chave: Eurocentrismo. Grupos Dirigentes. Alianças políticas. Parentelas.

\section{Apresentação ${ }^{3}$}

As relaçóes da política com outros universos sociais têm sido objeto de um conjunto de pesquisas que, de forma diversificada, aponta para o amálgama entre estes diferentes espaços. De um lado, um conjunto de autores preocupa-se em demonstrar em que medida os efeitos dessa conexão afeta a

I Pós-doutora e doutora em Sociologia pela Universidade Federal de Sergipe (UFS). É professora adjunta no Departamento de Ciências Sociais (DCS) da UFS e no Programa de Pós-Graduação em Sociologia (PPCS) dessa mesma universidade.E-mail: f.petrarca@hotmail.com

2 É professor Associado 3 da Universidade Federal de Sergipe (UFS), no Departamento de Ciências Sociais (DCS), no Programa de Pós-Graduação em Sociologia (PPCS) e Programa de Pós-Graduação em Antropologia (PPGA). Possui doutorado em Antropologia Social pela Universidade Federal do Rio Grande do Sul (UFRGS). E-mail: etnografia.politica@gmail.com ou etnografiasdapolitica@gmail.com

3 A pesquisa que deu origem a esse trabalho foi financiada pela Coordenação de Aperfeiçoamento de Pessoal de Nivel Superior (CAPES), através do Programa Nacional de Cooperação Acadêmica (PROCAD) NF 2009. pelo Conselho Nacional de Desenvolvimento Científico e Tecnológico (CNPq) e pela Universidade Federal de Sergipe (UFS). 
autonomia de determinadas esferas, comprometendo o que se produz nelas e gerando consequências na sua forma de organização. Nessas condições, a autonomia depende do enfraquecimento das posiçóes dependentes do campo político ou diretamente a ele associados. De outro lado, a preocupaçáo se volta para a dinâmica que assume essa relação em determinadas circunstâncias sociais, históricas, políticas e culturais.

Tomar como ponto de partida e princípio geral de análise os chamados processos históricos de separação, diferenciação e especialização de ordens de atividades distintas, tem sido uma das principais vias para o exame de tais relações. Todavia, aceitar como dado tal postulado não nos parece suficiente para dar conta dos processos concretos e das lógicas práticas que constantemente os une ou os distingue em diferentes contextos e situaçóes. $\mathrm{O}$ exame das condiçóes, dos processos e das lógicas de formação e de recomposição de grupos dirigentes constitui uma das alternativas pertinentes para a apreensão de como tais relaçóes são constantemente redefinidas e transformadas. Nesse artigo, tomamos como objeto de análise as dinâmicas de formação e de recomposição das elites dirigentes no estado de Sergipe. Interessa, portanto, demonstrar os diferentes níveis de associação com a política, as diversas formas de interseção e de politização.

Um dos conceitos que se apresentou como central para dar conta disso foi o de "parentela", uma vez que nos permitiu compreender como uma lógica centrada nas redes de base familiar conectava a política a outras esferas, como a das profissóes e a da política partidária. Primeiramente, mediante um conjunto de alianças "de base familiar" que sustentavam o controle das famílias que apenas poderiam dominar na condição de aliadas. Em segundo lugar, pela mobilizaçáo de um conjunto de recursos cada vez mais variados que contribuiu para a diversificação e ampliação da estrutura de capitais do grupo: títulos escolares, associações patronais, famílias, alianças políticas, alianças matrimoniais múltiplas, endogâmicas ou exogâmicas etc. E por fim, pelo processo de transformação das parentelas em redes de relaçôes diversificadas, cuja característica central é a manutenção dos laços de solidariedade fortes nas dinâmicas das elites dirigentes. Assim, tal análise demonstra as continuidades e transformaçóes dos processos e lógicas de constituição dos grupos dirigentes que mobilizaram, para além das redes de base familiar, as relaçóes e redes pessoais.

Nossa abordagem visa a fornecer elementos para um deslocamento dos debates sobre a politização como consequência da interferência da política em 
outras esferas sociais afetando sua autonomia. Para isso, daremos destaque ao aspecto descritivo e analítico dos processos de gênese e de consolidação da relação entre família, política e grupos dirigentes no estado de Sergipe. Um dos principais fundamentos das abordagens que partem dos chamados processos de politização está relacionado a um modelo ideal típico que em geral não se costuma realizar em nenhuma condição. Além disso, ela corresponde a uma categoria analítica que resulta de determinadas particularidades e sua universalização tende a se tornar um grave problema para as ciências sociais, uma vez que cria falsos objetos de análise. Uma das maneiras de evitar isso é historicizando e contextualizando essas categorias que se impóem como universais.

\section{“As parentelas não são jabuticabas"}

Como já é sabido, durante muito tempo as análises do poder e da política foram dominadas por pressupostos evolucionistas e eurocêntricos. Tais formulações tinham como base a dicotomia entre "sociedades primitivas" e "modernas" e a concepção da mudança e do desenvolvimento social e político como passagem do "natural", "simples", "arcaico" para o "racional", "complexo", "desenvolvido" etc. (BOCK, 1980). Nessa ótica, a caracterização das diversas formas de organização política e de suas transformações era concebida como uma passagem "necessária" da "não diferenciação das sociedades tradicionais" para o advento de "sociedades modernas" e diferenciadas (OLIVEIRA, 2015; DONEGANI, 2006).

As formulações de Parsons e Easton, centradas na ideia de "sistema político" e de "advento do Estado como resultado necessário de requisitos do tipo sistêmico" (DONEGANI, 2006, p. 6) são exemplos da permanência e longevidade de tais pressupostos na análise dos fenômenos políticos. Nessa perspectiva, as sociedades cujas formas de organização política não se encaixassem em tais definiçóes eram abordadas negativamente, na medida em que faltava a elas alguma propriedade ou atributo tido como essencial (PALMEIRA; GOLDMAN, 1996). Com base nessas noções, tais formas de organização social e política eram classificadas sob a tipologia da "falta", da "carência" e da "ausência”, como "sociedades sem Estado", "sociedades sem poder", "sociedades sem política” (CLASTRES, 1990; OLIVEIRA, 2015).

Isso porque as classificaçóes que pretendiam dar conta da variabilidade e diferença entre os sistemas políticos acabavam fazendo um recenseamento 
"das sociedades segundo a maior ou menor proximidade que seu tipo de poder mantém com o nosso [ocidental]", fundado no pressuposto de que há "uma continuidade entre todas essas diversas formas de poder" e "de que a História tem um sentido único", de modo que os primitivos eram vistos como "o que não somos mais" (CLASTRES, 1990, p. 14-15). É por isso que os procedimentos comumente utilizados para caracterizar as diversas formas de organização política seguiam classificações e tipologias que tomavam como base e medida a chamada política ocidental e as categorias que lhes eram próprias e particulares, tais como: comando-obediência, coerção e Estado (CLASTRES, 1990; DUMONT, 1993; LATOUR, 1994; GOODY, 2008). Assim, grande parte das tipologias acabou incorrendo em classificaçôes valorativas que estipulavam quantitativamente $\mathrm{o}+\mathrm{e} \mathrm{o}-\mathrm{do}$ poder e da política, de modo que aquelas situaçóes que se distanciavam empiricamente desse modelo dominante eram simplesmente definidas com base no uso de metáforas biológicas como "embrionário", "nascente", "pouco desenvolvido", bem como de designaçóes derivadas dessas, tais como: "não diferenciado", "pouco institucionalizado" etc.

Durante muito tempo, as análises do clientelismo ilustraram com clareza exemplar a continuidade e persistência de tais pressupostos na investigação dos fenômenos políticos. Ele era visto como fenômeno típico e praticamente exclusivo das situaçóes "não modernas" e, como tal, estava em total oposiçáo aos processos de politização que eram tidos como próprios das sociedades "modernas e ocidentais". Na medida em que tinha como base vínculos e benefícios diretos, pessoais e particularistas, o clientelismo constituía uma espécie de "arcaísmo político", de obstáculo à "modernização política" e à "politização democrática” (BRIQUET, 2003, 2017), tornando-se um termo estigmatizante das formas desviantes de desenvolvimento político e democrático (COMBES; VOMMARO, 2012) e, em razão disso, sendo o responsável pelas "limitaçôes" e "fragilidades" da democracia em situações como o Brasil e a América Latina, entre muitas outras. Quando observado nas instituiçóes políticas das "sociedades ocidentais" é sob o traço do "residual", da "disfunção" ou do "desvio" em relação aos objetivos institucionais legítimos que ele é geralmente considerado (BRIQUET, 2017, p. 29).

Foi no âmbito da ciência política que estas abordagens receberam maior apreço e audiência. Segundo tais perspectivas a "compra de votos" fundada nas 
teorias da escolha racional e do individualismo utilitário, tornou-se um domínio de análise estabelecido, reduzindo a relação de clientela a "uma transação entre dois indivíduos buscando maximizar seus ganhos", negligenciando "sua relação com formas de reciprocidade, obrigação, respeito", como também o peso das dimensões morais e simbólicas das relaçôes políticas de reciprocidade e troca (PALMEIRA; GOLDMAN, 1996; COMBES; VOMMARO, 2012, p. 20). Como oposto ao clientelismo e como parte dos processos históricos de diferenciaçáo, separação e institucionalização de ordens de atividades especializadas, os processos de politização constituíam a característica próprias das sociedades "modelares" e se definiam tanto pelas dinâmicas que propiciavam a separação entre a política e as adesóes e dependências locais, pessoais, familiares, comunitárias etc., quanto pela interiorização da linguagem e de ideologias dos profissionais da política por ordens de atividades diversificadas (profissionais, religiosas, econômicas, científicas etc.).

As primeiras reações a tais abordagens foram formuladas a partir da observação das tensôes e mudanças impostas pela colonização ocidental às "sociedades tradicionais" e se caracterizaram, entre outras coisas, pelo surgimento de perspectivas centradas no exame das modificaçóes impostas a tais sociedades e na reintrodução da história (OLIVEIRA, 2015). Tais iniciativas possibilitaram o afrontamento de pressupostos evolucionistas que estabeleciam certos elementos como inerentes ao exercício do poder e ao funcionamento da política (CLASTRES, 1990; DONEGANI, 2006). Mais importante ainda, para o que está em pauta nesse artigo, é que as referidas iniciativas conduziram ao questionamento do "advento do Estado" como inerente ao exercício do poder e da política (CLASTRES, 1990; OLIVEIRA, 2015) e colocaram sobre outras bases as interrogações sobre as "[...] condiçôes de aparição e de desenvolvimento de circuitos especializados" de poder que caracterizavam tanto as "sociedades ocidentais" quanto as "tradicionais", na medida em que podiam se exprimir das formas mais variadas, tais como parentesco, religiấo, Estado etc. (DONEGANI, 2006, p. 10-11). Nesse sentido, já que as funções políticas podem ser realizadas por meio de espaços, organizações e relaçóes que não são necessariamente "qualificadas de política", a política pode ser compreendida como uma espécie de "qualificação flutuante" de certas relaçóes sociais, impossibilitando determinar a priori sua essência (DONEGANI, 2006; OLIVEIRA, 2015). 
Iniciativas desse tipo tiveram um impacto relevante não apenas na análise das chamadas "sociedades tradicionais". Elas conduziram também a uma renovação do olhar sobre as próprias "sociedades ocidentais", ao salientarem as particularidades de suas formas de organização social e política, ao invés da aceitação tácita de sua generalidade e universalidade. Isso se mostra de maneira especial na crítica às dicotomias entre "ocidental" ou "moderno" e "não ocidental" ou "tradicional" que traduzem, entre outras coisas, uma grande divisão e hierarquização entre os fenômenos sociais e políticos segundo sua proximidade em relação ao que aconteceu no chamado "Ocidente". Para isso contribuiu, decisivamente, a crítica dos pressupostos subjacentes ao conceito de poder e de poder político e o questionamento da própria universalidade de tais formulaçôes, demonstrando como muitas das investigações e muitos dos resultados obtidos pelas pesquisas sobre tais fenômenos têm sido feitos com base em categorias que mais funcionam como "ideologias" do mundo ocidental, do que como conceitos universalmente aplicáveis a todas as sociedades (CLASTRES, 1990; LATOUR, 1994; GO, 2013).

Dando continuidade a esse tipo de crítica e aos problemas e desafios que ela levantou, os questionamentos posteriores sugeriram tratar de outra forma a chamada "política moderna" ou "ocidental". Ou seja, foi o questionamento da própria clivagem e divisão das sociedades que esteve no centro das discussôes e que se tornou uma das principais fontes para a renovação da agenda de pesquisa sobre os fenômenos políticos. Nesse sentido, Latour (1994) salienta o quanto essa divisão está diretamente associada à separação entre "Nós" e "Eles", ao mesmo tempo em que estabelece uma assimetria entre as sociedades. Em conformidade com isso, o "Nós" moderno - seja ele social, político ou cultural - geralmente é apresentado como algo coerente, distinto e que tem uma verdade em si e que deve servir de modelo para o conhecimento e avaliação dos outros povos ("Eles”).

Sem dúvida, é essa assimetria que está na base dos impasses recorrentes das caracterizaçóes dos diferentes sistemas políticos que têm como base esta ideologia. Por isso, deve-se evitar a aceitação tácita da "ontologia" que os "modernos" têm de si mesmos e que acaba limitando nossas pesquisas à busca dos "fatos" que comprovem a existência da modernidade política e seu grau de desenvolvimento nos diversos países do mundo contemporâneo. Pelo contrário, nosso desafio consiste justamente em abrir a "caixa preta" da fabricação da 
"política moderna", recompondo de forma sincrônica todas as mediaçôes entrelaçadas à sua imposição (LATOUR, 1994, p. 20-21; TROUILLOT, 2005; GOODY, 2008). E essa tarefa difere não somente da utilização corriqueira de caracterizaçóes da política que partem do pressuposto da universalidade do modelo Ocidental mas também daquele tipo de reflexão sobre a história das estruturas, sistemas, instituiçôes e práticas políticas nas mais diferentes sociedades, ainda centrada na ideia de exclusividade e exemplaridade europeias (GOODY, 2008; OLIVEIRA, 2015). Antes disso, trata-se de inserir a história das instituiçóes políticas modernas em suas relaçôes de proximidade, de concorrência e de dominação com a história das demais sociedades, como também de conectá-las às dinâmicas e relaçôes internacionais na constituição de valores, de instituiçóes e de práticas políticas, evidenciando como os ocidentais e a modernidade foram moldadas na e por suas relaçôes com os colonizados e os povos não europeus (GO, 2013).

Sáo problemas e desafios semelhantes que enfrentamos quando tomamos como objeto de análise os processos e as lógicas de formação e de recomposição dos grupos dirigentes no estado de Sergipe. Isso porque é usual tomar como ponto de partida e princípio geral para esse tipo de análise os processos históricos de separação, diferenciação e institucionalização de ordens de atividades especializadas e, consequentemente, de constituição de campos relativamente autônomos. Segundo essa perspectiva, as dinâmicas de formação e de recomposição dos grupos dirigentes nas sociedades ocidentais passaram a ser "mediatizadas por mecanismos objetivos e institucionalizados", tais como: um mercado econômico, um sistema de ensino, um aparelho jurídico, um Estado etc. (BOURDIEU, 1980, p. 224, 2005). Nestas situaçôes, as relaçóes de dominação entre os diferentes grupos sociais ocorreriam de forma "indireta e impessoal", na medida em que implicariam a existência e a mediação de mercados autorregulados, estruturados e institucionalizados que garantiriam a apropriação e a acumulação de diferentes formas de capital (BOURDIEU, 1980).

Em oposição a essas situações, as demais se caracterizam justamente pela ausência de alguns desses traços tidos como essenciais. Nestas situaçôes náo ocorreram os processos de diferenciação, separação e institucionalização de ordens de atividades especializadas, correlatos à constituição de mercados autorregulados, de campos ou setores de atividade autônomos. Ao contrário do que ocorreu naquelas sociedades, nestas situaçóes as dinâmicas de formação e 
de recomposição dos grupos dirigentes não passaram a ser mediadas por "mecanismos objetivos e institucionalizados" (mercado econômico, campo político, sistema de ensino, aparelho jurídico, aparato estatal etc.). Desprovidas da mediação de estruturas e instituiçôes que garantam a apropriação e acumulação de diferentes recursos e formas de capital, as relaçôes de dominação entre os diferentes grupos sociais em situaçôes como estas se dão de forma "direta e pessoal”, no sentido de que são exercidas mais diretamente entre pessoas. Em decorrência disso, estão centradas em estratégias e relaçôes personificadas e de reciprocidade como condição praticamente exclusiva de garantia da apropriação e acumulação de recursos diversificados.

Essa forma de classificação tem predominado nas análises das relaçóes da política com outras ordens de atividade e orientado as investigaçóes para o exame dos processos de politizaçáo. Nesse sentido, a política moderna tem sido caracterizada como um processo tanto de especialização e monopolização das atividades políticas por atores profissionalizados que dominam a linguagem e as regras do jogo próprias de um campo político autônomo, quanto de exclusão dos agentes sociais externos a tal campo. Sob esta ótica, como bem evidencia Briquet $(2003,2017)$, a politização é reduzida aos processos de "interiorização dos padrôes oficiais da política moderna" que requer o conhecimento, o domínio da linguagem e das regras da política institucional, característicos das dinâmicas de "modernização" e "politização democrática".

Do mesmo modo, as práticas de participação política e eleitoral acabam se tornando sinônimos da história do progresso na constituição de um mercado político que se impóe como legítimo e separado das relaçôes familiares, religiosas, étnicas, locais, comunitárias etc., e que implica a aquisição das disposições da política institucional e o domínio de seus códigos cognitivos e simbólicos (NEVEU, 1997; BRIQUET, 2017). Esse é também o tipo de abordagem geralmente utilizado na análise da produçáo da política em diferentes ordens de atividade. Para escapar das análises dos processos e das práticas de politização em ordens de atividade diversificadas fundadas em apreciaçóes morais e categorias normativas, Lagroye (2003) propóe relacioná-los aos processos históricos de separação ou distinção entre ordens de atividades, campos ou setores especializados (tais como a profissional, religiosa, econômica, artística, científica etc.). Nesses termos, os processos de politização consistem sempre em uma prática de "requalificação" da distinção ou separação entre tais ordens 
de atividade e a política, tomando a forma seja da transgressão ou da colocação em causa de tal diferenciação (LAGROYE, 2003).

Inserir as práticas clientelistas e as relaçóes pessoais que as fundamenta como parte de uma estrutura de dominação, com princípios e regras próprias, representou um significativo avanço para a análise dos fenômenos políticos, aproximando-se daquelas perspectivas que procuraram romper com as análises evolucionistas e eurocêntricas. Ao contrário destas, tais abordagens se centraram na apreensão dos laços clientalares em suas dinâmicas e regras próprias, ao invés de uma relação que pertence ao passado, um arcaísmo e um obstáculo à modernização política. Ao mesmo tempo, enfatizaram a importância do princípio da reciprocidade e do dom, colocando em jogo obrigaçóes morais e imperativos afetivos (COMBES; VOMMARO, 2012, p. 22; AUYERO, 1999; 2013; PALMEIRA; GOLDMAN, 1996). Todavia, no que pese o avanço da formulaçáo de tais características em termos de um modo de dominação próprio e da ruptura com as avaliaçóes morais e normativas, centradas no avanço ou retrocesso da democracia, tais tipologias da forma de configuração das relaçóes entre a política e as demais esferas de atividade ainda parecem dominadas por pressupostos e postulados que têm como base a universalidade dos modelos hegemônicos, bem como a separação, divisão e assimetria entre as sociedades.

Trata-se, primeiramente, de tipologias que aceitam tacitamente a universalidade do modelo ocidental, estabelecendo as diferenças entre as sociedades com base na existência ou inexistência de certos traços tomados como essenciais e que são exatamente aqueles que são considerados como característicos dos processos sociais e históricos ocorridos nos países dominantes. Por isso, mais do que simples diferenças, a separação entre a política e as demais ordens de atividade correlata à existência de mercados autorregulados constitui parâmetro decisivo para estabelecer as oposiçôes e hierarquias entre tais situaçôes. Desse modo, tais classificaçôes dão continuidade e renovam as divisóes e hierarquias entre as sociedades, que se manifesta pela prática corriqueira de estabelecer tipologias segundo a distância ou proximidade em relação aos processos sociais e históricos tidos como próprios do chamado "Ocidente".

Em segundo lugar, e como decorrente disso, ao invés de características contrastantes tal tipologia reestabelece as divisóes, clivagens e hierarquias entre "tradicional e versus moderno", "selvagem versus civilizada", "atrasadas 
versus desenvolvidas" etc. Nesse sentido, a presença de determinado atributo nessa situação corresponde exatamente à sua ausência na outra, fixando como opostos, antagônicos e excludentes princípios que podem funcionar de modo complementar e até mesmo simultâneo. Assim, as situaçóes desprovidas dos atributos e relaçóes que caracterizam as sociedades "modelares" e nas quais a dominação é sempre "direta e pessoal", são constantemente analisadas como aquelas que se caracterizam pela sobrevivência de relações e práticas ultrapassadas (clientelismo, familismo, relaçóes pessoais etc.) que já foram banidas nas sociedades centrais ou que, quando nelas observadas, se manifestam apenas de "modo residual e não estruturante" (CORADINI, 1996). A sobrevivência destas relaçóes e práticas é também considerada como a responsável pela "fraca institucionalização", pela "falta de autonomia" das instituiçóes e setores de atividade, pela "debilidade" e "inconsistência" da democracia etc.

Por fim, e não menos importante, essas perspectivas contribuem para a permanência e continuidade das análises que abordam negativamente as situaçôes "periféricas", acabando por obscurecer as condiçóes e as lógicas de formação e recomposição dos grupos dirigentes em tais situações. Nessa classificação são justamente estas situações aquelas que carecem dos atributos tidos como primordiais e que, por isso mesmo, se definem pela falta, uma vez que são aquelas nas quais tais atributos são inexistentes e que, consequentemente, são "desprovidas" de um conjunto de características relacionadas a tais atributos e consideradas essenciais. Assim, essa postura negativista constitui um dos fatores que está na base de certo desinteresse em compreender os significados e as lógicas da política em tais situaçóes.

No âmbito dos estudos dos grupos dirigentes no Brasil tais pressupostos e postulados ainda se fazem presentes, às vezes de modo implícito, dando origem a uma série de dificuldades e problemas analíticos. Em primeiro lugar, está uma aceitação tácita da divisão e oposição das sociedades entre "centrais versus periféricas", de "dominaçáo institucional" e de "dominação pessoal" etc. Associada a isso está a localizaçáo do Brasil no segundo tipo, conduzindo a uma série de conclusóes que apontam para o caráter "particularista" e "personalista" das relaçôes sociais e políticas e do funcionamento das instituiçôes, grupos e setores de atividade ${ }^{4}$.

4 Marco fundador desse tipo de análise na sociologia política brasileira é a obra de Sérgio Buarque de Holanda, "Raizes do Brasil". 
Diretamente vinculadas a essa ideia, destacam-se as tendências de importação, de utilização e de "difusão de abordagens conceituais, de problemáticas e de interpretações homogêneas" produzidas na Europa e nos Estados Unidos da América (EUA). Dito em outros termos, tomam-se as polarizaçóes e as dinâmicas de organização e funcionamento das instituiçóes que são características de países europeus e norte-americanos como padrão de relaçôes sociais, institucionais e políticas, concluindo que, em "sociedades como a brasileira", uma vez que os espaços não adquiriram a "relativa autonomia", como observado nesses países, eles são totalmente dependentes da esfera política. Logo, é esta que define as condiçóes de realização em outras esferas, como a profissional, intelectual, jurídica etc. (CORADINI, 1996; PÉCAUT, 1990). Tais formulaçôes têm como base a inserção e circulação de estudantes e pesquisadores entre grupos e redes de pesquisa vinculadas a universidades e instituiçóes dos EUA e da Europa, especialmente da França. Semelhante ao que tem acontecido em outras áreas de investigação (GOIRAND, 2009, 2010, p. 460; OLIVEIRA, 2013), isso contribui para que conceitos consagrados ou problematizados pela produção acadêmica internacional sejam aceitos sem maiores questionamentos a respeito de sua aplicabilidade para a situaçáo brasileira.

$\mathrm{Na}$ medida em que tais perspectivas atribuem um estatuto menor e secundário à persistência de laços, vínculos e relaçóes pessoais no "ordenamento das relaçóes sociais", elas desembocam facilmente para uma abordagem negativa de tais relaçóes. Como bem salienta Bezerra (2013), isso remete àquelas interpretaçôes que as colocavam como "sobrevivência de relaçôes tradicionais" ou, na melhor das hipóteses, como "indício de desenvolvimento incompleto" das instituições políticas. Uma vez que a posição da sociedade brasileira pende sempre para o lado desfavorável nessa assimetria estabelecida entre as diferentes sociedades e que a tendência de importação de conceitos e problemáticas torna-se predominante, tais vertentes contribuem também para certo desconhecimento e um constante distanciamento, e, até mesmo, esquecimento de uma ampla gama de estudos centrados nas condiçôes e dinâmicas próprias de constituição dos grupos dirigentes na situação brasileira (OLIVEIRA; PETRARCA, 2016).

Esse é particularmente o caso dos estudos sobre "parentela", "família extensa", "coronelismo", "clientelismo" etc., os quais são desenvolvidos desde um bom tempo para dar conta das condiçôes e dinâmicas de possibilidade de 
emergência e de reprodução dos grupos dirigentes no Brasil. E tais análises foram simplesmente esquecidas com base na importação de problemáticas europeias e norte-americanas. Por isso, muitos estudos recentes têm analisado as relações entre grupos familiares e política, com base na aceitação tácita das características de tais grupos em países europeus e, particularmente, na França. Esse é o caso da utilização da noção de "família" e de "grandes famílias" (OLIVEIRA; PETRARCA, 2016). A própria expressão "grande família” e os contornos que o uso desta expressão assume nos estudos sobre elites brasileiras demonstram que os trabalhos estiveram mais preocupados em caracterizar o grupo como uma unidade do que se ater concretamente ao sistema de relaçóes sociais que torna possível e que fundamenta sua existência no decorrer do tempo e em diferentes espaços. Nesse sentido, ao tomar como ponto de partida determinadas unidades familiares que se destacaram em diferentes cenários corre-se seriamente o risco de cair no "efeito de unificação simbólica" do grupo, contribuindo, assim, para a existência e legitimação do próprio grupo (OLIVEIRA; PETRARCA, 2016).

Sem dúvida, um dos maiores desafios no estudo dos grupos dirigentes, bem como na investigação dos fenômenos políticos em geral, consiste ainda em romper com essa assimetria entre os tipos de sociedade, ao mostrar que mais do que opostos, antagônicos e excludentes, os princípios que os constituem podem se manifestar de modo complementar e até mesmo simultâneo em uma mesma situação social. Em nosso caso, um dos conceitos que se tornou chave para definir essa questão foi o de "parentela", uma vez que nos permitiu compreender como uma lógica centrada nas redes de base familiar conectava a política a outras esferas, como a das profissóes e a da política partidária, entre outras. Nesse sentido, nossa análise do sistema de "parentela" não pretende fazer desta um traço "singular", "próprio” ou mesmo "ímpar" da sociedade brasileira: "uma jabuticaba" como posto pelo dito popular. Contudo, procuramos demonstrar como o sistema de parentela e as relaçóes pessoais remetem a relaçóes e a práticas políticas que têm como princípio ingredientes tanto da dominação "direta e pessoal” (vínculos de parentesco, relaçóes de amizade e camaradagem, obrigaçóes morais, sentimentos de gratidão e reciprocidade etc.) quanto da "indireta e impessoal" (lógicas oficiais, regras institucionais, prescriçóes partidárias etc.). Desse modo, procuramos nos aproximar daquelas perspectivas que destacam a necessidade de superar 
o que chamam de "a artificial bifurcação das relaçóes sociais" que tem como fundamento principal a repartição ou divisão das sociedades em "ocidentais" e "não ocidentais".

Este tipo de abordagem já tem sido utilizada em estudos sobre temas variados, tais como: politização, eleiçôes, participação política, Estado, administração pública, movimentos sociais etc., sugerindo que os fenômenos políticos podem ser considerados de outra forma. Tais estudos demonstram que relaçôes pessoais, de amizade, obrigaçóes morais e sentimentos de gratidão etc., apresentam-se como elementos constitutivos da administração pública, como um recurso importante na domesticação do Estado (BEZERRA, 2017), como também uma dimensão importante do recrutamento e da continuidade da atuação em organizaçóes e movimentos sociais (MCADAM; PAULSEN, 1993; DIANI; MCADAM, 2003; PASSY, 1998; FILLIEULE, 2001). Do mesmo modo, ao invés de constituir um obstáculo à "política moderna" e à democracia, diferentes estudos têm demonstrado que historicamente o clientelismo foi um mecanismo prático de adaptação das instituiçôes e categorias políticas modernas a situaçôes locais no decorrer do processo de formação e de consolidação das instituições democráticas (BRIQUET, 2017). Além disso, os vínculos personalizados de troca fazem parte de uma "economia moral" que fundamenta as formas concretas de apropriação e de sentido da política pelos atores sociais (AUYERO, 1999, 2006, 2013; COMBES; VOMMARO, 2012; BRIQUET, 2003, 2017).

Assim, tal conceito possibilita recusar as definiçóes substantivas dos grupos dirigentes, com base em perspectivas excludentes dos tipos de dominação, e de levar considerar a sobreposição ou imbricação de atividades sociais (política, religião, família, amizades etc.), ao abordar as várias formas de articulação ou combinação de atividades sociais com a política, de variabilidade de manifestação e de agentes que mobiliza. Por isso, trata-se de seguir as instituiçóes, os grupos e as pessoas, nas atividades que concretamente se envolvem ou se distanciam "quando dizem estar fazendo política" no intuito de apreender tanto os eventos e as práticas quanto as avaliaçôes e as concepçóes delas como políticas. Com base na descrição, análise e comparação, tal abordagem possibilita romper com as tipologias etnocêntricas ao se colocar como objetivo a apreensão das "[...] complexas maneiras pela quais uma determinada sociedade estabelece recortes de domínios, classificaçôes e descontinuidades 
significativas, bem como descrever e analisar o que em cada contexto é delimitado como pertinente à política” (COMERFORD; BEZERRA, 2013, p. 467-468).

\section{Os Grupos Dirigentes, as Lideranças Políticas e as Alianças em Sergipe}

Nosso modelo de análise visa a demonstrar que a parentela, como forma de organização social, tem se apresentado como uma chave importante para compreender as conexôes entre as chamadas "famílias de elite", a política e outras esferas. Como já apontado pela literatura sociológica, a parentela estava na base das relaçôes sociais dos grupos dirigentes, estruturando suas relaçóes entre diferentes espaços, sobretudo de meados do século XIX até as primeiras décadas do século XX (CANDIDO, 1951; LEWIN, 1993; QUEIROZ, 2006; WAGLEY, 1971). Tanto a liderança política, como a formação dos espaços profissionais, por exemplo, emergem do "jogo entre parentelas" em que predominavam as associaçôes entre relaçôes familiares amplas (filhos, sobrinhos, afilhados, cunhados, sogros) e afinidades (amizade política).

Utilizada pela literatura, já citada, para representar um tipo específico de relaçóes de base familiar, a parentela representou uma dinâmica marcada pelo domínio dos proprietários rurais - que eram chefes políticos locais denominados também de coronéis ${ }^{5}$ - e baseada nos arranjos, muitas vezes incertos e instáveis, entre famílias e afins (aliados políticos, afilhados, amigos). A característica central era, portanto, sua organização em torno de uma rede de reciprocidade e de lealdade que ultrapassava a família nuclear (pai + mãe = filhos).

Assim, para as próprias elites dirigentes brasileiras a noção de família ia além do seu núcleo consanguíneo e tornava-se cada vez mais extensa incluindo: parentes lineares (pai, irmãos, avós e netos), parentes colaterais (tios, sobrinhos, primos), parentes não consanguíneos integrados pelo casamento (genro, cunhado, concunhado, sogro, tios) ou por laços de compadrio e

5 No início do século XIX, o termo coronel representava uma posição associada à Guarda Nacional. Contudo com a extinção deste título, os coronéis continuaram se atribuindo essa denominação que passou a representar um tipo de poder local com base na barganha entre governo e oligarquias locais, das quais os coronéis eram os principais representantes. 
compadresco $^{6}$ (afilhados adotados ou admitidos). Essa particularidade demonstra a habilidade em incluir novos membros, colocando as amplas alianças como parte indispensável desse processo. Além disso, a parentela correspondia a um sistema complexo no qual poderiam conviver, na condição de aliadas, tanto as famílias de estratos sociais desiguais, quanto aquelas que estavam no mesmo nível socioeconômico. $\mathrm{O}$ que garantia a união era a solidariedade, entendida aqui como dependência recíproca, e a lealdade. Nessas condiçôes, não se pode falar em "domínio familiar", visto que poucos são os casos em que uma família controlava sozinha a política, mas em "relaçóes de base familiar" em que prevaleciam as alianças entre diferentes parentelas (CANDIDO, 1951; QUEIROZ, 2006; LEWIN, 1993).

A parentela representava a unidade política menor deste sistema de alianças cobrindo a vida social dos municípios e estados. Dela derivaram os agrupamentos políticos e a oligarquia, sua expressão máxima. Sua emergência representa a expansão do Estado brasileiro tendo como núcleo o município, uma vez que as dificuldades enfrentadas por Portugal para dominar e povoar o país, devido à sua dimensão continental, conduziram ao incentivo do poder e autonomia dos senhores rurais, chefes das parentelas. A consequente independência do país colocou aos proprietários rurais a necessidade de enviar representantes às câmaras municipais e, em seguida, às câmaras provinciais (QUEIROZ, 1976). Para formar essas lideranças políticas a ocupar esses cargos, os coronéis estabeleciam acordos e faziam alianças a partir de suas relaçóes familiares.

Essa situação não sofreu abruptas rupturas com a República Velha. Muito pelo contrário, as lideranças que constituíram o novo regime eram resultado do Império e mantiveram os arranjos políticos historicamente associados às estruturas baseadas nas alianças e resultantes dos laços de amizade política e de parentesco. Para sobreviver a esse novo sistema político, o investimento das famílias foi cada vez mais frequente nos laços externos ao parentesco, incluindo a incorporação dos cunhados, dos concunhados e dos amigos políticos ao grupo familiar. $\mathrm{O}$ resultado disso foi um sistema fundamentado na sua forma máxima de configuração e alianças que foi a política oligárquica (LEWIN, 1993). O Estado centralizador de Vargas, a partir de 1930, também não

6 O compadresco representa a relação espiritual que deriva do ritual religioso de batismo, crisma ou casamento. Já o compadrio é a relação social que deriva deste tipo específico de parentesco: o afilhado. 
conteve essa dinâmica que demonstrou sua capacidade de renovação, diversificando ainda mais, a partir deste período, sua base de alianças.

\section{Diagrama I - Parentela}

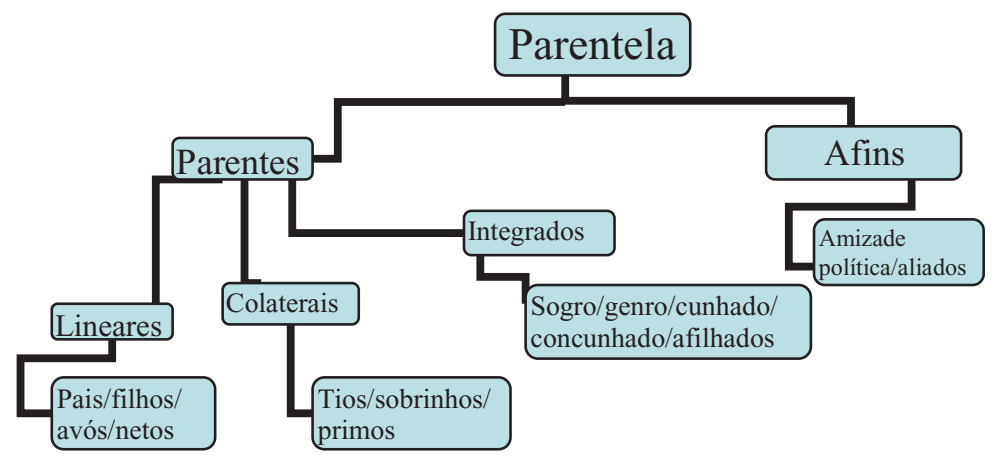

Fonte: Elaborada pelos autores.

Nas economias regionais menos ricas e nos estados politicamente dependentes de outras regióes, como é o caso de Sergipe, o controle destas famílias por meio das alianças era quase absoluto. Por ser considerado um "estado satélite" 7 , Sergipe nos fornece o modelo deste sistema fundado na força das parentelas para o controle da política. Um elemento fundamental que afetou a composiçáo destes grupos foi o caráter fragmentário da terra. Comparado aos estados vizinhos, Bahia e Pernambuco, os engenhos de Sergipe eram de baixo e médio porte, ocupando uma área territorial de pequena extensão, o que permitia a existência de vários engenhos em um mesmo município. Em geral, as famílias possuíam propriedades que abrangiam quatro ou cinco municípios, o que tornava a aliança com outros proprietários indispensável no controle da região. Este tipo de domínio que se formou não era exercido, portanto, por uma única família, mas por várias delas conectadas - pelo casamento ou por vínculos políticos e de amizade - e que dominavam a partir das alianças, fortalecendo a relação entre parentes e afins. E eram estruturadas a partir das

7 Partindo da definição de Linda Lewin (1993), estado satélite é aquele que produz não para um centro, mas para manutenção de outro estado do qual é dependente. No caso de Sergipe, sua produção era voltada para a Bahia, estado que estava sujeito à influência política e econômica. 
divergências e dos conflitos pelo controle e escoamento da produção do açúcar, tais grupos familiares aliados controlavam todos os postos locais, como de médico, juiz, tabeliáo e até mesmo de pároco. Tal confronto entre proprietários de engenho dividiu o estado em duas principais regiôes produtoras de açúcar que cobriam 2/3 do seu território: regiâo do Cotinguiba e Vaza Barris (DANTAS, 2004, 2009). Em cada uma destas regiôes, havia o domínio de um conjunto de chefes políticos locais que tentavam controlar suas alianças em um delicado equilíbrio.

Desse modo, em Sergipe as parentelas refletiram uma combinação de fortes lealdades pessoais e articulação entre laços familiares e aliança política. Do ponto de vista organizacional, era muito semelhante à Paraíba e a outros estados vizinhos cuja característica central era sua dependência e subordinação política e econômica. Enquanto Sergipe estava subordinado à Bahia, os estados da Paraíba, Ceará, Alagoas, Rio Grande do Norte eram subordinados à Pernambuco (LEVINE, 2006). Estes “estados satélites” são, em geral, considerados como mais dependentes das relaçôes familiares (LEWIN, 1993).

A primeira oligarquia sergipana, também considerada uma das primeiras do Brasil ${ }^{8}$, foi constituída pela parentela de Almeida Boto ${ }^{9}$ e sustentada por violentos conflitos no controle dos municípios para produção e escoamento do açúcar, principal atividade econômica do estado. Em meados de 1840, Almeida Boto liderava as forças políticas conservadoras locais em oposiçáo ao grupo de Araújo Maciel e Travassos. Sua ascensão foi, em parte, resultado das alianças com base nas relaçóes familiares e vínculos políticos que soube bem constituir. Suas propriedades resultam, de um lado, da herança dos pais - colonizadores portugueses que ocupavam a maior regiáo no escoamento do açúcar no estado (Cotinguiba) - e de outro, do casamento com uma viúva proprietária de três engenhos e irmã de José de Barros Pimentel, comandante das Armas ${ }^{10}$ e importante coronel e chefe político local (DANTAS, 2009). De início, ele mobilizou os principais recursos da época para consolidar seu poder econômico e político: herança e alianças matrimoniais. Do matrimônio pôde

8 Segundo Vianna (1999), as primeiras oligarquias brasileiras emergem nos estados de Sergipe e Piauí.

9 Conhecido como "Napoleão do Poxim".

10 Cargo mais alto na administração das províncias, tinha por incumbência administrar as forças políticas $e$ militares. 
não só ampliar sua propriedade, garantindo controle na região, como também estreitar os laços com o cunhado, essencial para alavancar sua carreira política. A valorizaçáo dos "laços de cunhadio" se tornou, no interior das parentelas, importante meio de consolidar alianças entre famílias.

Sua parentela é formada, fundamentalmente, por alianças políticas e familiares amplas, sobretudo os laços familiares colaterais extensos e os obtidos pelo casamento - como os observados com o cunhado José de Barros Pimentel e, posteriormente, com Bento de Melo Pereira, presidente da Província, casado com sua tia, irmã do seu pai. Junto com Bento, (Capitão-Mor, comandante das Armas e Barão de Cotinguiba) e José Pinto de Carvalho (chefe político e aliado), Almeida Boto controlou as forças políticas locais com o apoio dos Regentes Nacionais (DANTAS, 2016). Os investimentos nessas alianças resultaram na ocupaçáo do cargo de presidente da província, interinamente, por cinco vezes e na liderança oligárquica.

Mas como a ascensão ao topo da parentela não era definida pela herança consanguínea, as disputas entre as lideranças em torno de qualidades, laços e vínculos pessoais se tornavam a marca central da formação destes grupos. Assim, era muito comum um aliado abandonar o chefe de uma parentela se julgasse ter sido ofendido ou não atendido em suas ambiçóes pessoais e passar a apoiar outra liderança. $\mathrm{O}$ resultado disso era um equilíbrio delicado e uma luta marcada pelo desentendimento constante entre as lideranças, pela formação de novos blocos, emergência de dissidências e grupos opositores. Depois de se envolver em assassinatos por herança e acumular alguns desafetos ao longo dos seus investimentos familiares e políticos ${ }^{11}$, Almeida Boto já começa a perder alguns dos seus principais apoiadores que foram se unindo a chefes políticos locais adversários. Duas situaçóes ilustram essa dinâmica. A primeira foi o confronto aberto que travou com Manoel Joaquim Fernandes de Barros, médico formado na universidade de Strasburgo, considerado o homem mais ilustrado da província do seu tempo. Manoel, que era aliado de Travassos parentela concorrente -, casou-se com a viúva de José de Barros Pimentel, cunhado de Boto. As brigas por herança e os litígios familiares levaram ao assassinato de Fernandes de Barros, o que contribuiu para desestabilizar as

11 As brigas por herança colocavam "em xeque" as relações políticas, promovendo a divisão dos grupos e a criação de novas facções. 
alianças políticas de Almeida Boto. A segunda foi o desentendimento com João Gomes de Melo (Barão de Maruim), seu amigo, compadre e grande aliado, que passou a apoiar outros chefes políticos do Partido Conservador, ampliando sua liderança no controle dos municípios do eixo Cotinguiba.

Com o intuito de evitar seu declínio aparente, Boto migra, já no final da década de 1840, para o Partido Liberal, visto que no âmbito federal havia um investimento grande nos liberais em detrimentos dos conservadores ${ }^{12}$. E, em seguida, casou-se com a irmã de Antônio Dias Coelho, filho do Barão de Itaporanga, "Senhor do Engenho Escurial" 13 e futuro Baráo de Estância, que disputava o controle do Partido Liberal. Essa união fortaleceu os "laços de cunhadio" e conectou Boto com a parentela dos Dias Coelho. Ela ganhou força também com o investimento em alianças matrimoniais múltiplas, como o casamento entre as duas filhas de Boto com os dois filhos do Barão. O casamento de duas irmãs de uma família com dois irmãos de outra foi uma das principais formas de se estabelecer alianças no interior das parentelas, uma vez que aumentava a solidariedade entre os grupos devido à adição de afinidades: irmãos, cunhados e concunhados (LEWIN, 1993). Essa união garantiu aos Dias Coelho a liderança regional do Partido Liberal, ampliando o poder de influência deste grupo que se intensificou, mais adiante, através da aliança com os Rollemberg ${ }^{14}$.

O período de controle da oligarquia de Almeida Boto é visto pela historiografia local como de relativa estabilidade. Com o seu declínio, no final de 1840 até 1855 , os presidentes de Sergipe eram chefes políticos de outros estados, em geral baianos, com o objetivo de mediar os conflitos violentos entre as lideranças locais. Ao mesmo tempo, a derrota sucessiva de Boto permitiu a emergência de outras lideranças que em uma disputa acirrada tentavam controlar os municípios. A partir de meados da década de 1850, "era a vez da gente do Barão" exercer o domínio oligárquico referindo-se ao Barão de Maruim,

12 As revoltas liberais ocorridas em Minas Gerais e São Paulo no inicio da década de 1840, levaram o Imperador a indicar governantes que enfraquecessem Boto. Foi assim que o governo imperial o demitiu da presidência da provincia e elegeu Pereti, que era pernambucano, com o objetivo de diminuir os conflitos existentes entre Boto e seus adversários. Isso permitiu que os Liberais, como Travassos, ganhassem força (DANTAS, 2016).

13 Considerada uma das mais importantes propriedades produtoras de açúcar do eixo Vaza-Barris.

14 Essas duas familias (Rolemberg e Dias Coelho) se uniram por laços matrimoniais e de aliança, e passaram a controlar os dois grandes eixos de produção e escoamento do açúcar: Cotinguiba e Vaza Barris. 
João Gomes de Melo -, visto que, além de deputado geral, acumulava o título de Comandante Superior da Guarda Nacional dos municípios de Rosário, Maruim e Divina Pastora (DANTAS, 2009). Filho de proprietários rurais canavieiros, cujas terras abrangiam quatro municípios do eixo Cotinguiba ${ }^{15}$, seu ingresso na política ocorreu pela associaçáo com a parentela de Almeida Boto, por laços de compadrio, e de maneira semelhante ao seu compadre e ex-aliado, seu primeiro consórcio com viúva proprietária de três engenhos, Maria José Rollemberg, permitiu que ele concentrasse suas propriedades nesses municípios, fornecendo as condiçóes iniciais para o controle da regiáo. Contudo, como se sabe, as alianças eram parte fundamental desse processo e mantê-las exigia habilidade. João Gomes de Melo cresceu como força política no interior do Partido Conservador liderando uma importante facção e captando, após seus desentendimentos com Boto, seus aliados. Atingiu seu apogeu em 1855 na articulação entre os grupos do eixo Cotinguiba e Vaza Barris, após promover a mudança da capital São Cristóvão para a cidade de Aracaju. Dois importantes aliados se destacam: Visconde de Uruguai e Inácio Barbosa. O primeiro, seu cunhado, por conta do segundo consórcio, tornou-se peça-chave na aproximaçáo com o Imperador; o segundo, importante aliado político local. A influência junto ao Imperador, por intermédio do cunhado, garantiu a indicação de Inácio Barbosa à presidência da província, condição fundamental para aprovação da troca de capitais junto à Assembleia Legislativa.

Contudo, os conflitos em torno das qualidades pessoais e da capacidade de expansão dos laços para formar um bloco era difícil de ser administrada e exigia habilidade política. Barão de Maruim, por exemplo, era chefe político de um bloco ${ }^{16}$, dentro do Partido Conservador, que contava com alguns remanescentes do Partido Liberal e liderava uma parentela controlando alguns municípios, sobretudo as proximidades de Maruim e Santo Amaro das Brotas. José de Trindade Prado, Barão de Propriá, seu aliado político, chefiava uma parentela que controlava a região de Propriá. Seus concorrentes controlavam o norte do Estado prevalecendo em alguns municípios, como Pacatuba e Propriá, como Barão de Cotinguiba que era aliado de Almeida Boto. Este último ainda que tenha perdido o controle da oligarquia, exercia forte influência

15 São eles: Rosário do Catete, Siriri, Santo Amaro das Brotas e Japaratuba.

16 Seu bloco denominava-se Saquarema e, durante alguns anos, conseguiu o controle do Partido Conservador. 
em Itaporanga D’Ajuda e Estância, por meio do seu cunhado, o Barão de Estância.

Soma-se a isso a administração das alianças matrimoniais a fim de garantir o controle da parentela. Essa foi uma das dificuldades enfrentadas pelo Barão de Maruim quando seus enteados - dentre eles, o Barão de Japaratuba (Gonçalo Acioli de Faro Rollemberg) e Ana de Faro Rollemberg - uniram-se pelo matrimônio com outras famílias de chefes políticos locais, como os Dias Coelho, os Prado, Sampaio e Madureira e passaram a construir seus próprios grupos. Isso se tornava um problema quando os filhos se casavam porque eles herdavam os engenhos. E como essas propriedades de médio porte estavam situadas próximas, em conjunto formavam uma grande propriedade, intensificando a necessidade das alianças. As tensôes, já no final de 1850 , por herança, conduziram a divisóes e à emergência de dissidências que, por sua vez, contribuíram para a perda da liderança e sua fragmentação.

De 1860 até a Proclamação da República, em 1889, passou a acontecer um constante revezamento entre liberais e conservadores. Esses partidos, que na verdade funcionavam como sedes das parentelas, passavam constantemente por divisóes internas e eram afetados pelo aparecimento de facçóes que acabavam por romper. Essa tendência à fragmentação provocou a emergência e o declínio de várias lideranças e chefes locais, cujo poder de dominação tinha, em geral, vida curta. Segundo Dantas (2009), de 1868 até 1877, apesar do predomínio dos conservadores, aconteceram quinze 15 mudanças de presidente de província. Esse período, todavia, não pode ser subestimado, uma vez que permitiu o crescimento de algumas parentelas que tiveram impacto na política sergipana no período republicano, como os Rollemberg. A família, que se aliou por matrimônio com outras ${ }^{17}$, ao mesmo tempo em que ampliou sua base de alianças mantendo-se no controle da esfera política, enfraqueceu o grupo de origem. Mais do que o casamento interfamiliar, eles investiram no casamento extrafamiliar. Um marco importante na formação dos Rollemberg enquanto um grupo político foi o casamento entre José de Faro Rollemberg, filho do Barão de Japaratuba, e Amélia Dias Coelho, filha do Barão de Estância. Esse consórcio aliou os Dias Coelho que exerciam uma influência

17 São exemplos as alianças dos Rollemberg, em seus diversos troncos (filhos, sobrinhos, netos), com as seguintes familias: Madureira, Dias Coelho, Prado, Leite, Sampaio, Menezes, Franco. 
significativa no eixo Vaza-Barris, junto com os Boto, com os Rollemberg da região do Cotinguiba. Mas foi, principalmente, o casamento entre o médico Gonçalo de Faro Rollemberg (sobrinho de José de Faro e neto do Barão de Japaratuba) com Aurélia Dias Coelho, segunda filha do Barão de Estância, que consolidou os vínculos entre essas duas famílias.

A passagem do Império para a República representou um momento de mudanças significativas na reorganização dos grupos. No âmbito estadual, com a "política dos governadores", os grupos passaram a ter mais autonomia na definição e no recrutamento para ocupação de posto políticos. Disso resultam duas unidades fundamentais de recomposição oligárquica: de um lado, fortaleceram-se os grupos de base familiar originando-se no município; de outro, ampliaram-se as alianças, tornando as redes individuais estabelecidas em âmbito estadual e federal fundamentais. Essas redes dependeram, fundamentalmente, dos bacharéis que, ao terem de estudar fora dos limites do município e do estado, passaram a formar seus próprios vínculos e os conectaram com suas bases familiares, diversificando dessa forma as conexóes. Nessa direção, cresce expressivamente, nas disputas entre os grupos, o peso do título de bacharel obtido nas faculdades de direito e medicina, em detrimento de outros recursos propriamente imperiais, como o título de barão. A profissão médica e jurídica tornam-se os principais canais de poder destes grupos.

Este contexto, da recém-instituída República, foi marcado, em Sergipe, pelo confronto entre as oligarquias locais e muitas interferências do presidente da República na política local que acabava por tumultuar a construção de governos e a formação de quadros políticos locais. Conforme Dantas (2009), a escassa vivência política de Sergipe e sua diminuta formação de quadros políticos locais com experiência no jogo político nacional constituem um dos principais pontos dessa fragilidade.

Os movimentos revolucionários republicanos tiveram pouco eco no estado, segundo a historiografia local. Os clubes republicanos foram criados em apenas cinco dos 33 municípios existentes (DANTAS, 2009). Foram os proprietários de engenho, desgostosos com a abolição da escravatura e atingidos pelos prejuízos financeiros decorrentes desta, que estiveram à frente do movimento republicano. A fundaçáo do Partido em 1888, na cidade de Laranjeiras, importante polo açucareiro, por proprietários rurais, formados nas faculdades de medicina e direito, marca a reorganização das oligarquias e 
dos chefes locais. Alguns nomes se destacam, como o do médico Felisbelo Freire, primeiro governador do período republicano, e dos bacharéis em direito Martinho Garcez, Fausto Cardoso e Sílvio Romero. Esses dois últimos, apesar de terem feito carreira no Rio de Janeiro, onde residiam, influenciavam a política sergipana.

Contudo, as divisóes no interior do partido pela liderança das parentelas e as redes externas estabelecidas em âmbito federal destituíram Felisbelo do cargo. Depois de alguns confrontos, o nome do General Oliveira Valadão, que ocupava uma posição de destaque junto ao presidente da República, Marechal Floriano Peixoto, em função de sua participação na Guerra do Paraguai, passa a representar esse novo agrupamento.

Valadão, que estava longe da sua terra mas ao lado do seu genro Joaquim Pereira Lobo, passou a compor a nova oligarquia da era republicana denominada Valadáo-Lobo, a qual contou com o apoio de um conjunto de chefes políticos locais ligados ao bloco de parentelas chamado "Pebas". Essa oligarquia, apesar de ter tido vida curta (de1896 até 1898), revela o realinhamento das forças locais e demonstra a capacidade dos grupos de garantir sua permanência na política através da criação e manutenção de alianças. Teve impacto significativo o movimento liderado por Silvio Romero ${ }^{18}$ no Rio de Janeiro que interferiu nas forças políticas locais elegendo, em 1896, Valadão para presidência do Estado.

O bloco dos "Pebas" sofria a concorrência do bloco dos "Cabaús"19. Enquanto o primeiro se concentrava em Aracaju, o segundo estava ligado a lideranças locais que se reuniam na região dos engenhos. Esses blocos representaram duas grandes dissidências políticas que surgiram em Sergipe no final do século XIX e que levaram à constituição de duas fortes lideranças: Valadão e Olímpio Campos. Frente a essa configuração os partidos republicanos náo conseguiram imprimir uma força, permanecendo, como no período anterior, subsidiário do sistema oligárquico (DANTAS, 1989).

18 De uma família de proprietários de engenho de médio porte no municipio de Lagarto, Silvio Romero formou-se em direito pela escola de Recife em 1873 e no ano seguinte foi nomeado promotor de Estância onde ficou até 1875. Esse periodo foi intercalado pelo cargo de deputado provincial juntamente com o amigo Martinho Garcez. Em 1876, foi nomeado juiz de direito de Parati, no Rio de Janeiro; a partir dai, seguiu carreira de jornalista, advogado e literato. Em 1894, retornou a Aracaju e junto com seu irmão Benilde Romero, este chefe político liberal de Lagarto e juiz de direito, lançou-se novamente na política.

19 Nome dado em alusão ao mel escuro dos engenhos de açúcar. 
No que diz respeito à sua composição, ambos contavam com o apoio e liderança dos proprietários rurais, donos de engenho, cujo predomínio estava na região açucareira. Por um lado, o grupo dos "Pebas" contava com os bacharéis que haviam liderado o movimento republicano e que eram oriundos das faculdades de medicina e direito de Recife, Rio de Janeiro e Bahia, fortalecendo as redes individuais estabelecidas fora do estado e intensificando o poder das parentelas internamente. Por outro lado, os "Cabaús" eram constituídos pelos proprietários de engenho das regiôes mais dominantes do estado na produção do açúcar e contavam amplamente, também, com os bacharéis que os possibilitavam conectar sua influência interna com as redes externas. Diferente dos "Cabaús", os "Pebas" contavam com proprietários rurais de regióes onde era menor a influência econômica nos engenhos, como Lagarto, Simão Dias e Itabaiana, e, por isso, mesclavam sua produção com o comércio, a criação de gado e a agricultura.

\section{Diagrama 2 - "Os Pebas"}

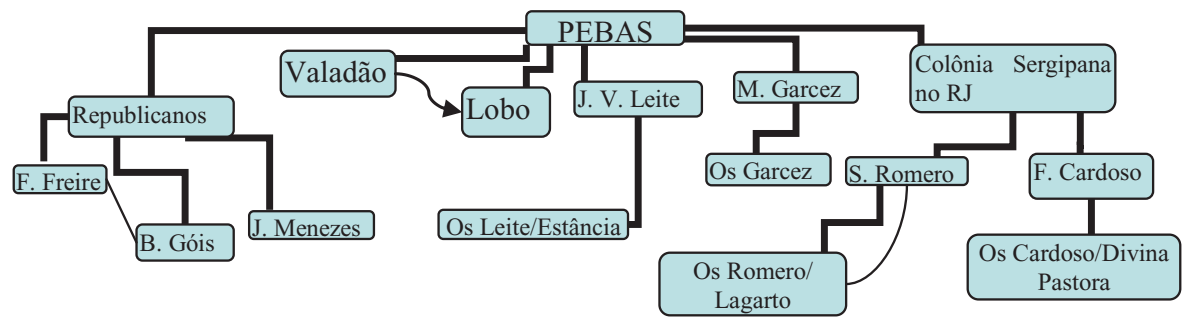

Legenda: linha reta (tio); linha curva seta (genro); conector em curva (irmão).

Fonte: Elaborada pelos autores.

O Diagrama 2 representa graficamente a composição dos "Pebas", que contou com os líderes do movimento republicano em Sergipe, como Felisbelo Freire, seu tio Baltazar Góis e o aliado Josino Menezes. Além da chamada "colônia sergipana no Rio de Janeiro" que contava com Silvo Romero e Fausto Cardoso $^{20}$, sob a liderança do primeiro. Silvio Romero, filho de um dos

20 Formou-se na escola de direito de Recife em 1884 e um mês depois já estava nomeado promotor de Capela. Mais tarde, exerceu a função em Gararu, Riachuelo e Laranjeiras. Em 1890, mudou-se para o Rio de Janeiro e lá atuou na política junto a Floriano Peixoto. Entre 1900-1902, tornou-se deputado federal. Em 1906, retornou para Aracaju como a nova promessa contra a oligarquia olimpista. 
mais bem-sucedidos comerciantes de Lagarto ${ }^{21}$ junto com os irmãos Benilde Romero (juiz), Joveniano Romero (médico) e Nilo Romero (promotor), e outras lideranças locais, exerciam força política no município disputando com os Dantas. Fausto Cardoso era filho de coronel ${ }^{22}$ proprietário de engenho do município de Divina Pastora e destacado líder político local. O grupo ainda contava com Martinho Garcez, bacharel em direito, amigo de Silvio Romero, e João Vieira Leite, da parentela dos "Leite de Estância"23. Esse agrupamento conectou as alianças de base familiar à amizade política que passou a se tornar cada vez mais forte no contexto republicano.

As divisóes internas no grupo dos "Pebas" levou ao enfraquecimento da oligarquia Valadão-Lobo, cedendo lugar a Olímpio Campos que passou a comandar o estado com o grupo dos "Cabaús". Como destaca o diagrama a seguir, o grupo era composto, fundamentalmente, por lideranças do eixo Vaza-Barris e Cotinguiba. De um lado, estava a parentela dos Rollemberg com força nos dois eixos e Costa Dória no norte do estado; de outro, Leandro Maciel e Olímpio Campos. Este último cresce politicamente como representante do agrupamento devido à sua intensa habilidade de estabelecer alianças. Filho de um coronel situado na região do Vaza Barris e chefe político do Partido Conservador na vila de Itabaianinha, envolveu-se já no começo da sua carreira nas rixas entre os Dantas e os Romero, principais famílias que disputavam os postos locais em Lagarto. O pai de Olímpio Campos era rival político de João Dantas Martins dos Reis, do engenho Fortaleza, que controlava a região de Riachão do Dantas, nas proximidades de Lagarto. Mas Campos, ao eleger-se deputado geral, estabeleceu uma aliança com os Dantas. E, com a morte de João Dantas, Campos ampliou sua influência na região sul do estado.

21 André Ramos Romero, comerciante português, ao contrair matrimônio com Maria Silveira Ramos, filha de proprietários de engenho, destacou-se na articulação bem-sucedida entre comércio, propriedade rural e agricultura, tornando-se comendador em 1869

22 O tenente coronel Félix Zeferino Cardoso militava no partido Conservador ao lado de Leandro Maciel e era ligado por laços de parentesco com Almeida Boto.

23 Importante familia de Estância estava conectada pelo matrimônio com os Carvalho; entretanto, investiu, sobretudo, nas alianças matrimoniais endogâmicas, como casamento entre primos, o que levou os Leite a fecharem sua base de alianças. 


\section{Diagrama 3 - "Os Cabaús"}

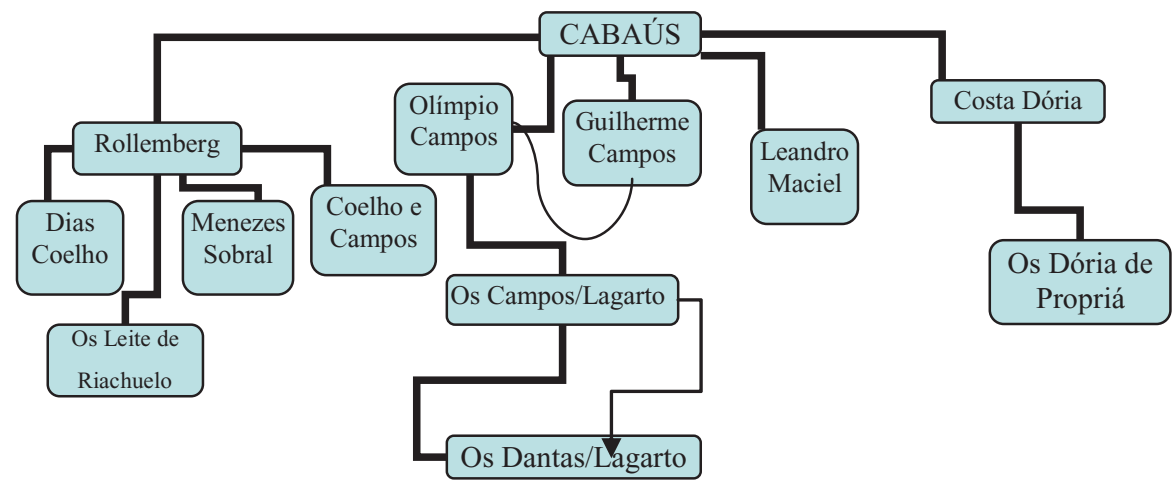

Legenda: seta (aliado político); conector em curva (irmão) Fonte: Elaborada pelos autores.

As dissidências internas também afetaram os "Cabaús" e já nos primeiros anos, em 1903, encontravam-se fragmentados e fragilizados. A indicação que Olimpio Campos fez de Josino Meneses, antigo republicano vinculado originalmente aos "Pebas", para que este o substituísse no governo do Estado enquanto se dirigia ao senado, dividiu os "Cabaús". Aqueles que rejeitaram Josino acabaram por se juntar com os adversários de Campos, apoiando mais tarde Fausto Cardoso (DANTAS, 2007, 1999). Valadáo, enfraquecido como liderança local, juntou-se a Olimpio Campos em 1903. Em 1906, parte dos "Pebas" apoiou Campos, destacando-se o acordo feito por Martinho Garcez em troca da eleição de Romero e Cardoso para Câmara de deputados e seu próprio cargo ao senado.

Todavia, a forte repressão instaurada aos focos de tensão levou à prisão de três cunhados do desembargador Gumercindo Bessa, dos "Pebas", colocando o já frágil acordo em jogo. O desembargador passa a liderar, no âmbito local, uma violenta campanha contra Campos e, em nível nacional, Silvio Romero assumiu o lugar de ferrenho oposicionista da oligarquia Campos. Apoiados por um conjunto de coronéis, inclusive aqueles desgostosos com Campos, da região do Cotinguiba e parte do Agreste, com um total de 11 municípios, a revolta ganhou força (OLIVA, 1985). O grupo liderado por Silvio Romero se reorganizou e trouxe, na linha de frente, o nome de Fausto Cardoso. Pode-se 
afirmar que o bloco da oposição era constituído por Leandro Maciel, Fausto Cardoso, Silvio Romero, Martinho Garcez e outras lideranças locais. Ao fim da disputa com a Revolta de 1906, entre faustistas e olimpistas, ocorreu a morte de Fausto Cardoso. E o assassinato de Olímpio Campos....

Contudo, a morte das duas principais lideranças oligárquicas concorrentes não colocou fim ao jogo das parentelas. Olimpistas e Faustistas se revezaram no comando do Estado até os anos 1930. A oligarquia Olimpista permaneceu até 1911 com o governo do médico Costa Dória e a oligarquia Valadão-Lobo até a Revolução de 1930 com o governo de Gracco Cardoso. O novo regime instaurado em 1930 no âmbito federal permitiu a reorganização dos grupos. O mesmo ocorreu em 1945, em 1964 e nos anos 1980 com a redemocratização. Cada um destes regimes exigiu a recomposição das relações de força locais e pôde experimentar tanto o crescimento de diferentes agrupamentos que combinavam sua base familiar com suas redes externas quanto a emergência de vários tipos de acordo e vínculos. "O mosaico das alianças tivera todos os coloridos possíveis” (LEITE, 2008, p. 138). Tiveram impacto nessa recomposição dos grupos dirigentes as alteraçóes na atividade econômica dos membros da elite que se tornou mais diversificada com o declínio da produção de açúcar e com o crescimento do mercado de postos profissionais e atividade empresarial, com a urbanização. Um exemplo disso foi o grupo dos "Leite de Riachuelo" que investiram amplamente nas redes de base familiar e nas redes profissionais, controlando os principais postos políticos até a década de 1950 e os "Franco", mais direcionados a cena empresarial, após a década de 1960 (PETRARCA, 2017).

Assim como no resto do país, os alinhamentos familiares determinavam os alinhamentos partidários, conduzindo a formação de correntes dissidentes no interior desta instituição. Essas dissidências organizavam-se em torno da combinação entre afiliaçóes de base familiar e personalística e se tornaram um padrão de organização e reorganização dos grupos dirigentes no estado. A própria configuração da pequena propriedade que conduzia às alianças, a estrutura de dominação colegiada que permitia iguais poderes e autonomia aos chefes políticos locais, como também a inexistência de uma ideologia partidária que se impusesse ao sistema político local, são alguns dos fatores que contribuíram para consolidação da política faccional. Intrigas políticas, desavenças de ordem pessoal e pequenas afrontas compunham o sistema de 
formação e desconstrução das facçóes constituindo-se como um dos principais padrôes de relações (QUEIROZ, 1976). A propensão para a fragmentaçáo nos permite compreender que os grupos dirigentes náo alcançaram graus de hierarquização rígidos.

Os períodos seguintes se destacaram pelo investimento progressivo nas redes, muitas vezes construídas nos espaços profissionais, que se tornaram mais amplas e extensas. Enquanto o "grupo" correspondia a uma parentela (amigos de longa data definidos como quase-parentes e parentes consanguíneos ou recrutados pelo casamento), a rede interligava facçóes individuais. Elas se tornaram mais ilimitadas e permitiram conectar politicamente os níveis local, estadual e federal. Esse processo de valorização das redes se inseriu nessa dinâmica de diversificação das parentelas. Contudo, foi longo e associado a um crescente reconhecimento dos "afins" para os grupos familiares, ou seja, daqueles que vinham de fora e que foram adquirindo relativa importância nas disputas por posiçóes políticas. Na medida em que os laços de sangue ou aqueles obtidos pelo casamento não asseguravam mais a posição na política e não eram garantia de confiança, uma alternativa que se abriu foi a amizade política baseada nos alinhamentos familiares, nos laços profissionais, estendendo assim a rede e conectando o município ao nível federal. As redes dependiam cada vez mais de membros não parentes para conectar o nível local ao poder político federal.

Como se pode perceber, a lógica que une as complexas associaçóes entre o espaço da política e outras ordens de atividade como as da família, da amizade, das profissóes, é a lógica da aliança fundada nas redes de relaçóes amplas que funcionam como importante capital social. A parentela, de um lado, nos permite compreender a gênese dessas alianças e, de outro, sua própria expansão a partir da base familiar. $\mathrm{Na}$ medida em que os laços familiares foram entrando em conflito com as transformaçóes sociais e econômicas, no curso dos anos 1920, a amizade política e também aquelas oriundas dos espaços profissionais foi tomando o lugar antes ocupado pelas relaçóes familiares.

\section{Conclusões}

As relaçóes da política com os demais mundos sociais foram e ainda são dominadas por pressupostos e ideologias eurocêntricas. Nesse sentido, o ponto 
de partida e de chegada para tais análises é a aceitação tácita da "ideologia da modernidade" que estabelece como "dado" e "evidente" a clivagem entre as sociedades conforme a existência ou não de processos de separação, diferenciação e especialização de ordens de atividades distintas, a exemplo do que se acredita ter ocorrido de forma original e modelar nas chamadas sociedades ocidentais. As análises dos processos de politização se tornaram um dos loci privilegiado para a avaliação do grau de interiorização e de realização da política moderna nas mais diferentes situaçôes sociais, estigmatizando como opostos a tais processos, fenômenos que, mesmo nas sociedades centrais, desempenham função semelhante de apropriação e de experimentação da política. É o caso exemplar do clientelismo, o "familismo", as relaçóes pessoais etc. que são constantemente vistos como sobrevivência de relaçôes e práticas ultrapassadas.

Em nossos estudos sobre a formação e recomposição dos grupos dirigentes de Sergipe, algumas noçôes que foram universalizadas com base na experiência europeia, tais como "família”, "campo", politização etc., não se apresentaram como categorias-chave para dar conta tanto das relaçóes e dos conflitos entre os principais grupos dominantes quanto dos vínculos por eles estabelecidos com diferentes universos sociais. Como demonstramos no decorrer desse artigo, é o conceito de parentela que apresenta uma importante contribuição heurística, já que nos permite apreender o papel central que desempenharam os laços sociais e o sistema de alianças nas dinâmicas de composição e de recomposição dos grupos dirigentes. Nesse sentido, ele contribui para o avanço nas formas de compreender a conexáo entre diferentes mundos sociais que, como se sabe, passa cada vez mais pela compreensáo da lógica que os une. Nesse caso, é a lógica da aliança que se sobressai como traço destacado das relações entre os principais grupos políticos no poder. Por isso, o exemplo sergipano se torna fundamental, uma vez que as próprias condiçóes de fragmentação conduziram à produção de um sistema cujo componente central é a necessidade constante de estabelecer alianças. Assim, mais do que a "herança" (familiar), é a competência para manter e estabelecer novas alianças que constitui um recurso fundamental de êxito e sucesso político.

Tais relaçôes e base de recursos não devem ser encaradas como uma "peculiaridade" da situação em pauta, uma "singularidade" ou uma "jabuticaba". Mas, uma chave para compreender determinados aspectos da realidade que contribui para colocar em jogo os quadros de referência pretensamente 
universais, como as noções de família e herança ou as de separação entre ordens de atividades distintas e politização. Aos nos permitir compreender como se fazem e se desfazem alianças e qual seu peso no processo de formação dos grupos dirigentes, o sistema de parentela se torna um caminho para superar as interpretaçóes essencialistas das experiências nacionais e, em particular, da brasileira, porque esta se expressava na imagem de um projeto moderno cristalizada nas abordagens clássicas do pensamento social brasileiro.

Assim, o principal desafio que se coloca para as ciências sociais atualmente consiste em um duplo exercício: descrever as múltiplas formas de dominação e organização políticas e romper com as clivagens e antagonismos entre as sociedades fundados em pressupostos etnocêntricos que, geralmente, desembocam para avaliaçóes valorativas e normativas. E, da busca por novos conceitos que determinem tanto as diferenças quanto as regularidades entre os modos de dominação, quando dissociada desse duplo exercício, surge o risco de a antiga "tese da singularidade brasileira" ganhar novos contornos, embora durante muito tempo tenha sido considerada a forma persistente de conceber a realidade nacional. Mesmo que se observem atualmente renovadas tentativas de se afastar do debate normativo a respeito do "dilema nacional" ou da "questão nacional", persiste ainda a aceitação tácita do descompasso entre a sociedade brasileira e as chamadas sociedades centrais da modernidade, o que conduz ao sentimento de "eterno" desencaixe da sociedade brasileira em relação aos retratos modelares impostos pelos países que assumiram a posição de protagonista do projeto moderno.

Uma saída para esse problema é investigar - a partir de determinados contextos históricos, políticos e sociais - como se combinam diferentes recursos, esferas e ordens de atividade, princípios e formas de dominação, o que resulta em uma multiplicidade de arranjos possíveis. Esse raciocínio abre caminho para uma alternativa ao dilema sociológico da modernidade. Nossa pretensão, como sugere Tavolaro (2005, p. 16), “[...] demanda, antes de tudo, um esforço analítico por meio do qual as diversas combinaçóes e transformaçôes por que passou (ou por ventura poderá vir a passar) a sociedade brasileira (tanto quanto as chamadas "sociedades modernas centrais") sejam devidamente apreendidas e consideradas". 


\section{Referências}

AUYERO, J. "From the client's point(s) of view": How poor people perceive and evaluate political clientelism. Theory and Society, v. 28, n. 2, p. 297-334, 1999.

. Introductory Note to Politics under the Microscope: Special Issue on Political Ethnography I. Qualitative Sociology, v. 29, n. 3, p. 257-259, set. 2006.

- A rede de solução de problemas do peronismo. Revista Brasileira de Ciência Política, n. 10, p. 107-150, 2013.

BEZERRA, M. O. Representantes Políticos, Relaçôes Pessoais e Reputação. In: SEIDL, E.; GRILL, I. G. (Org.). As Ciências Sociais e os Espaços da Política no Brasil. 1. ed. Rio de Janeiro: Fundação Getúlio Vargas, 2013. v. 1. p. 279-318.

Corrupção e produção do Estado. Revista Pós Ciências Sociais, v. 14, n. 27, p. 99-130, 2017.

BOCK, K. Teorias do Progresso, Desenvolvimento e Evolução. In: BOTTOMORE, T.; NISBET, R. História da Análise Sociológica. Rio de Janeiro, Zahar Editores, 1980. p. 65-117.

BOURDIEU, P. Le sens pratique. Paris: Éditions de Minuit, 1980.

Da Casa do Rei à Razão de Estado: um modelo da gênese do campo burocrático. In: L. WACQUANT; CASTANHEIRA, P. C. (Org.). O mistério do ministério: Pierre Bourdieu e a política democrática. 1. ed. Rio de Janeiro: Revan, 2005, p. 41-69

BRIQUET, J.-L. La Politique au Village. Vote et mobilisation électorale dans la Corse rural. In: LAGROYE, J. La politisation, Socio-histoires. Paris: Belin, 2003. p. 31-45.

- Pertencimentos locais, experiências cotidianas e práticas políticas: clientelismo e politização na Córsega (séculos XIX e XX). Revista Pós Ciências Sociais, v. 14, n. 27, p. 17-31, 2017.

CANDIDO, A. The Brasilian Family. In: SMITH, T. L.; MARCHANT, A. (Ed.). Brazil, portrait of a continent. New York: The Dryden Press, 1951. p. 291-312.

CLASTRES, P. A Sociedade contra o Estado. Pesquisas de Antropologia Política. Rio de Janeiro: Francisco Alves, 1990.

COMBES, H.; VOMMARO, G. Relations clientélaires ou politisation: pour dépasser certaines limites de l'étude du clientélisme. Cahiers des Amériques latines, v. 69, p. 17-35, 2012. 
COMERFORD, J. C.; BEZERRA, M. O. Etnografias da política: uma apresentação da Coleção Antropologia da Política. Análise Sociológica, 207, v. XLVIII, p. 465-489, 2013.

CORADINI, O. L. Grandes famílias e elite "profissional” na medicina no Brasil. História, Ciências, Saúde-Manguinhos, v. 3, n. 3, p. 425-466, 1996.

DANTAS, I. Os Partidos Políticos em Sergipe (1889-1964). Aracaju: Ed. Tempo Brasileiro, 1989.

O Tenentismo em Sergipe. Aracaju: Grafia Editora J. Andrade Ltda., 1999.

História de Sergipe República (1889-2000). Rio de Janeiro: Tempo Brasileiro, 2004.

A Trajetória política de Olympio de Souza Campos. Revista do Instituto Histórico e Geográfico de Sergipe, n. 36, p. 225-239, 2007.

Leandro Ribeiro de Siqueira Maciel. O Patriarca do Serra Negra e a Política Oitocentista em Sergipe (1825-1909). Aracaju: Criação, 2009.

A Política em Sergipe Provincial. Revista do Instituto Histórico e Geográfico de Sergipe, n. 46, p. 33-42, 2016.

DIANI, M.; MCADAM, D. (Org.). Social movements and networks: relational approaches to collective action. Oxford; New York: Oxford University Press, 2003.

DONEGANI, J-M. De l'anthropologique au politique. Raisons politiques, n. 22, p. 5-14, mai 2006.

DUMONT, L. O Individualismo. Uma perspectiva antropológica da ideologia moderna. Rio de Janeiro: Rocco, 1985.

FILLIEULE, O. Post scriptum: propositions pour une analyse processuelle de l'engagement individuel. Revue française de science politique, v. 51, n. 1, p. 199-215, 2001.

GO, J. For a postcolonial sociology. Theory and Society, v. 42, Issue 1, p. 25-55, jan. 2013.

GOIRAND, C. Movimentos sociais na América Latina: elementos para uma abordagem comparada. Estudos Históricos, Rio de Janeiro, v. 22, n. 44, p. 323-354, 2009.

Penser Les Mouvements Sociaux d'Amérique Latine. Les approches des mobilisations depuis les anneés 1970. Revue Française de Science Politique, Paris, v. 60, n. 3, p. 445-466, 2010. 
GOODY, J. O Roubo da História. Como os europeus se apropriaram das ideias e invenções do Oriente. Sáo Paulo: Contexto, 2008.

LAGROYE, J. Les Processus de Politisation. In: LAGROYE, J. (Dir.). La politisation. Paris: Belin, 2003. p. 359-372

LATOUR, B. Jamais Fomos Modernos. Ensaio de Antropologia Simétrica. Rio de Janeiro: Editora 34, 1994.

LEITE, R. Júlio Leite O Chefe Invisível. 2. ed. Aracaju: Gráfica Triunfo, 2008.

LEVINE, R. Pernambuco e a Federação Brasileira. In: FAUSTO, B. et al. História Geral da Civilizaçáo Brasileira (1889-1930). Rio de Janeiro: Bertrand Brasil, 2006. p. 130-171.

LEWIN, L. Política e Parentela na Paraíba. Um estudo de caso da oligarquia de base familiar. Rio de Janeiro: Record, 1993.

MCADAM, D.; PAULSEN, R. Specifying the Relationship Between Social Ties and Activism. American Journal of Sociology, v. 99, n. 3, p. 640-667, 1993.

NEVEU, C. Anthropologie de la Citoyenneté. In: ABÉLÈS, M.; JEUDY, H. P. (Org.). Anthropologie du politique. Paris: Armand Colin, 1997. p. 69-90

OLIVA, T. Impasses do Federalismo Brasileiro: Sergipe e A Revolta de Fausto Cardoso. São Paulo: Paz e Terra, 1985.

OLIVEIRA, W. J. F. A Arte de Resistir às Palavras: inserção social, engajamento político e militância múltipla. In: SEIDL, E.; GRILL, I. G. (Org.). As Ciências Sociais e os Espaços da Política no Brasil. 1. ed. Rio de Janeiro: Fundação Getúlio Vargas, 2013. v. 1. p. 141-178. Antropologia, política e etnografia: fronteiras disciplinares e trabalho de campo. In: PERISSINOTTO, R.; CODATO, A. N. (Org.). Como estudar elites. 1. ed. Curitiba: Editora UFPR, 2015. p. 187-214,

.; PETRARCA, F. R. Os Estudos de Elites no Brasil: um ensaio crítico sobre a produção recente. In: REIS, E. T.; GRILL, I. G. Estudos sobre Elites Políticas e Culturais. 1. ed. São Luís: EDUFMA, 2016. v. 2. p. 141-165.

PALMEIRA, M.; GOLDMAN, M. (Org.). Antropologia, voto e representaçáo política. Rio de Janeiro: Contra-Capa Livraria, 1996.

PASSY, F. L'action altruiste: contraintes et opportunités de l'engagement dans les mouvements sociaux. Genève: Droz, 1998. 
PÉCAUT, D. Os intelectuais e a política no Brasil. São Paulo: Ed. Ática, 1990.

PETRARCA, F. R. De coronéis a bacharéis: reestruturação das elites e medicina em Sergipe (1840-1900). Revista Brasileira de História, São Paulo, v. 37, n. 74, jan./abr. 2017.

QUEIROZ, M. I. P. de. O Mandonismo local na vida política brasileira e outros ensaios. São Paulo: Editora Alfa-Omega, 1976.

Coronelismo numa interpretação sociológica. In: FAUSTO, B. Et. al. História da

Civilizaçáo Brasileira. Rio Janeiro: Bertrand Brasil, 2006. Tomo III. v. 8. p. 172-212.

TAVOLARO, S. B. F. Existe uma Modernidade Brasileira? Reflexóes em torno de um dilema sociológico brasileiro. Revista Brasileira de Ciências Sociais, v. 20, n. 59, p. 5-22, 2005.

TROUILLOT, M.-R. Moderno de Otro Modo. Lecciones caribeñas desde el lugar del selvage. Tabula Rasa - Revista de Humanidades, v. 14, p. 79-97, 2011.

VIANNA, F. J. de. O. Instituiçóes Políticas Brasileiras. Brasília: Senado Federal, 1999.

WAGLEY, C. An Introduction to Brazil. 2. ed. New York: Columbia University: Ed. Press, 1971.

\section{Parentelas, Leadership Groups and Political Alliances}

\section{Abstract}

This article uses the concept of "parentelas" as an heuristic contribution that allows us to understand the central role of the social ties and alliances in the making of the leadership groups. Our approach aims to provide elements for change the debates about politicization as a consequence of separation and interference between distinct and autonomous activity orders. This perspective demands pay greater attention to the description of the multiple forms of political domination and organization, and especially the rupture with the cleavages and antagonisms between societies based on Eurocentric presuppositions and ideologies.

Keywords: Eurocentrism. Leadership groups. Political alliances. Parentelas.

Recebido em: 01.06.217

Aprovado em: 30.08.2017 